\title{
Instrument Development On Measuring Malaysian Households' Intention To Practise Solid Waste Segregation-At-Source
}

\author{
Kai Wah Cheng, Syuhaily Osman, Zuroni Md Jusoh, Jasmine Leby Lau
}

\begin{abstract}
The grade of the environment is gradually declining especially when it comes to the severe problem of solid waste. It has become a challenging burden for many large metropolitan heterogeneous areas in most of the developing countries. The main purpose of this research is to investigate the relationship between households' attitude, descriptive norm and injunctive norm with intention to practise solid waste segregation-at-source and to ascertain the mediating effect of environmental concern and moderating effect of environmental knowledge between households' attitude, descriptive norm and injunctive norm with intention to practise solid waste segregation-at-source. The instrument is then validated from four main aspects: face validity, content validity, convergent validity and discriminant validity. After the validation process, the pre-test of this research instrument is conducted among 30 Malaysian households. All the statements have been adjusted after reliability and validity test. The final version of the instrument is set in both closed and open format which consists of eight sections: respondent's particulars (11 items), general questions on solid waste segregation-at-source (7 items), attitude (14 items), descriptive norm (12 items), injunctive norm (12 items), environmental concern (three subparts and 12 items), environmental knowledge (25 items) and intention to practise solid waste segregation-at-source (8 items). The instrument can further be used to examine other similar research areas such as sustainable consumption, recycling as well as solid waste management.
\end{abstract}

Index Terms: Attitude, Descriptive Norm, Environmental Concern, Environmental Knowledge, Injunctive Norm, Instrument Development, Intention to Practise Solid Waste Segregation-at-Source

\section{INTRODUCTION}

Malaysia is a transition nation which is now experiencing fast population growth [1-2], rapid changing lifestyle [3], great urbanisation [2,4] along with aggressive economic development [5] and consumption rates [6]. As a result, these changes at the national level have raised several severe environmental concerns [7] in terms of energy security, the volume rate of municipal solid waste [8] and daily solid waste generation in Malaysia.

A large amount of municipal solid waste generation has become a challenging burden for many large metropolitan

Revised Manuscript Received on April 19, 2019.

Kai Wah Cheng, Department of Resource Management \& Consumer Studies, Universiti Putra Malaysia, Serdang, Malaysia.

Syuhaily Osman, Department of Resource Management \& Consumer Studies, Universiti Putra Malaysia, Serdang, Malaysia.

Zuroni Md Jusoh, Department of Resource Management \& Consumer Studies, Universiti Putra Malaysia, Serdang, Malaysia.

Jasmine Leby Lau, Department of Resource Management \& Consumer Studies, Universiti Putra Malaysia, Serdang, Malaysia. heterogeneous areas in most of the developing countries, especially Malaysia. In order to handle this public health issue, the recycling programme was first launched in Malaysia since the year 1993. However, it failed in getting much significant progression in it due to the lukewarm attitude and lack of households' participation [9]. Hence, it was re-launched by the Malaysian Ministry of Housing and Local Government in December 2000 [4].

Malaysian government aims to reach the 22 per cent national recycling target and 100 per cent recovery for the urban solid waste segregation-at-source by the year 2020 [2]. In accordance with the effort of government authority to have better solid waste management, Malaysian Ministry of Housing and Local Government declared 11th November as the National Recycling Day. In fact, the best way to managing the solid waste generation should be started from solid waste reduction at the source [10]. Starting from 1st September 2016, all Malaysian households in Johor, Melaka, Negeri Sembilan, Putrajaya, Kuala Lumpur, Kedah, Perlis and Kuantan are mandatory to practise solid waste segregation-at-source according to various solid waste compositions under Solid Waste Management and Public Cleansing Act 2007 (Act 672). They are cardboard, plastic, paper, food waste, glass, metal, farm waste, and lump waste. Likewise, it is an offence under the law for not separating solid waste at the source.

Households are also encouraged to play their significant social responsibility by practising recycling behaviour so as to preserve and protect the environment for the welfare of present and future generations [11]. However, it can be said that many of the environmental problems today are actually caused by the factor of attitude rather than technical problems [12] because it takes a long time to break the old traditions and alter the current attitudes and practices [13]. In this case, research, education, and public participation are some of the useful tools for long-term improvement and change in the ethics and attitude of the public towards proper waste management [14].

Unfortunately, in terms of the research discussion, there is no specific research which primarily focusing on the intention to practise solid waste segregation-at-source that can be found in the context of Malaysia [15]. The ongoing challenges in implementing solid waste segregation-at-

Published By

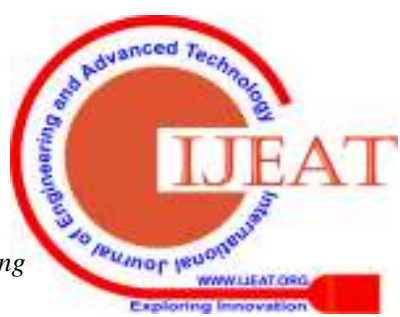


International Conference on Recents Advancements in Engineering and Technology (ICRAET-18) |15th and 16th March 2019|Siddhartha Institute of Technology \& Sciences, Telangana, India.

source behaviour for a long-term in Malaysia still require a bigger and clearer picture towards the current scenario in order to raise the rate of effectiveness and efficiency of this policy. Therefore, this research has assumed that it has become a necessity to explore the importance to have the intention to practice solid waste segregation-at-source behaviour among Malaysian households. Ultimately, the main purpose of this research is to investigate the relationship between households' attitude, descriptive norm, and injunctive norm with intention to practise solid waste segregation-at-source as well as to ascertain the mediating effect of environmental concern and moderating effect of environmental knowledge between households' attitude, descriptive norm, and injunctive norm with intention to practise solid waste segregation-at-source.

\section{LITERATURE REVIEW}

The publication of Development, Implementation, and Evaluation of Environmental Education Programmes by Stapp [16] triggered the growth of public awareness about environmental concerns since the late 1960s [17]. McKeown and Hopkins [18] highlight the importance of protecting the natural environment by developing the environmental consciousness and awareness to society. The society must have a certain level of understanding of the importance of nature (biotic and physical) and mankind [19]. Indeed, this feeling is rather organic for the harmonium development of personality as a member of certain society who is willing to solve the major environmental problems which including loss of biodiversity, global climate change, overconsumption of natural resources, deforestation, ozone layer depletion and natural pollution [20].

It is also important to stress that, fast population growth [1], rapid changing lifestyle [3], great urbanisation [4] along with aggressive economic development [5] and changes in consumption rate [6] have accelerated the daily generation and volume rate of municipal solid wastes in Malaysia. Consequently, the increases in the quantity of municipal solid waste have led to many negative environmental issues in Malaysia [21]. More terribly, it is reported that there is about 60 per cent of the 32 million Malaysians fail to throw their garbage into rubbish bins [22]. Therefore, Malaysian households should cultivate the intention to practise solid waste segregation-at-source immediately for a better and ideal living environment for the next generation in the future [23].

Previously, the dependent variable of intention to practise solid waste segregation-at-source behaviour has been investigated in various scopes of research. For examples, personality and social psychology [24], social psychology [25], environmental psychology [26-27], sustainable consumption [28], human ecology [29], health communication [30], and environmental management [31].

Subsequently, throughout the literature search, there are a number of factors influencing the intention to practise solid waste segregation-at-source. Table 1 shows a look back at how the selected similar research of intention to practise solid waste segregation-at-source unfolded.
Table 1: Chronology of Selected Research Closely Related to Intention to Practise Solid Waste Segregationat-Source

\begin{tabular}{|c|c|c|c|}
\hline Author (s) & Factors & $\begin{array}{l}\text { Types of } \\
\text { paper }\end{array}$ & $\begin{array}{ll}\text { Field } & \text { of } \\
\text { research }\end{array}$ \\
\hline $\begin{array}{l}\text { Kok and Siero } \\
{[32]}\end{array}$ & $\begin{array}{l}\text { Awareness, } \\
\text { comprehensio } \\
\text { n, attitude, tin } \\
\text { recycling } \\
\text { intention, tin } \\
\text { recycling } \\
\text { behaviour }\end{array}$ & $\begin{array}{l}\text { Empirica } \\
\text { l: } \\
\text { Quantitat } \\
\text { ive }\end{array}$ & $\begin{array}{l}\text { Economic } \\
\text { psychology }\end{array}$ \\
\hline $\begin{array}{l}\text { Davies, Foxall, } \\
\text { and Pallister } \\
{[33]}\end{array}$ & $\begin{array}{l}\text { Attitude, } \\
\text { recycling } \\
\text { intention, } \\
\text { actual } \\
\text { recycling } \\
\text { behaviour }\end{array}$ & $\begin{array}{l}\text { Empirica } \\
\text { l: } \\
\text { Quantitat } \\
\text { ive }\end{array}$ & Marketing \\
\hline $\begin{array}{l}\text { Chen and Tung } \\
\text { [34] }\end{array}$ & $\begin{array}{l}\text { Perceived lack } \\
\text { of facilities, } \\
\text { consumers' } \\
\text { recycling } \\
\text { intention }\end{array}$ & $\begin{array}{l}\text { Empirica } \\
\text { l: } \\
\text { Quantitat } \\
\text { ive }\end{array}$ & $\begin{array}{l}\text { Environmen } \\
\mathrm{t} \quad \text { and } \\
\text { behaviour }\end{array}$ \\
\hline $\begin{array}{l}\text { Mahmud and } \\
\text { Osman [35] }\end{array}$ & $\begin{array}{l}\text { Theory of } \\
\text { Planned } \\
\text { Behaviour, } \\
\text { recycling } \\
\text { intention }\end{array}$ & $\begin{array}{l}\text { Empirica } \\
\text { l: } \\
\text { Quantitat } \\
\text { ive }\end{array}$ & $\begin{array}{l}\text { Social and } \\
\text { behavioural } \\
\text { sciences }\end{array}$ \\
\hline $\begin{array}{l}\text { Ramayah, Lee, } \\
\text { and Mohamad } \\
{[36]}\end{array}$ & $\begin{array}{l}\text { Attitude, } \\
\text { value, green } \\
\text { product } \\
\text { purchase } \\
\text { intention }\end{array}$ & $\begin{array}{l}\text { Empirica } \\
\text { 1: } \\
\text { Quantitat } \\
\text { ive }\end{array}$ & $\begin{array}{l}\text { Resources, } \\
\text { conservatio } \\
\mathrm{n} \quad \text { and } \\
\text { recycling }\end{array}$ \\
\hline $\begin{array}{l}\text { Ittiravivongs } \\
\text { [37] }\end{array}$ & $\begin{array}{l}\text { Theory of } \\
\text { Planned } \\
\text { Behaviour, } \\
\text { responsibility, } \\
\text { perceived } \\
\text { facility } \\
\text { condition, } \\
\text { economic } \\
\text { incentive, } \\
\text { intention to } \\
\text { recycle }\end{array}$ & $\begin{array}{l}\text { Empirica } \\
\text { l: } \\
\text { Quantitat } \\
\text { ive }\end{array}$ & $\begin{array}{l}\text { Environmen } \\
\mathrm{t} \text { and energy }\end{array}$ \\
\hline $\begin{array}{l}\text { Fröhlich, } \\
\text { Sellmann, and } \\
\text { Bogner [38] }\end{array}$ & $\begin{array}{l}\text { Situational } \\
\text { emotion, } \\
\text { connectedness } \\
\text { with nature, } \\
\text { intention for } \\
\text { sustainable } \\
\text { consumer } \\
\text { behaviour }\end{array}$ & $\begin{array}{l}\text { Empirica } \\
\text { l: } \\
\text { Quantitat } \\
\text { ive }\end{array}$ & $\begin{array}{l}\text { Environmen } \\
\text { tal } \\
\text { education }\end{array}$ \\
\hline
\end{tabular}




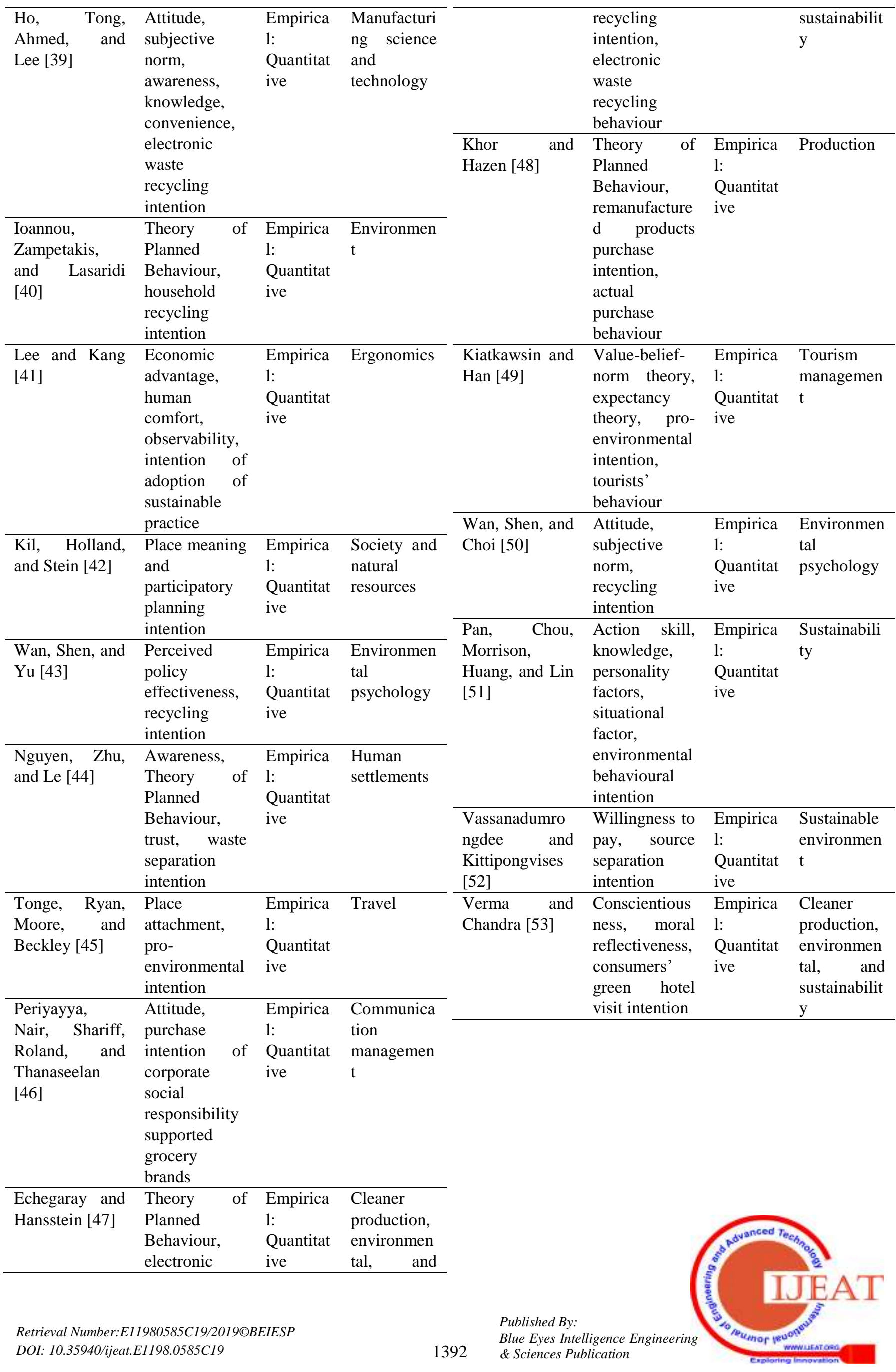


International Conference on Recents Advancements in Engineering and Technology (ICRAET-18) |15th and 16th March 2019|Siddhartha Institute of Technology \& Sciences, Telangana, India.

\begin{tabular}{|c|c|c|c|}
\hline $\begin{array}{l}\text { Vuong and } \\
\text { Nguyen [51] }\end{array}$ & $\begin{array}{l}\text { Perceived } \\
\text { price, } \\
\text { perceived } \\
\text { quality, brand } \\
\text { consciousness } \\
\text { conshion } \\
\text { consciousness } \\
\text { hedonic } \\
\text { shopping } \\
\text { value, store } \\
\text { environment, } \\
\text { sales } \\
\text { promotion, } \\
\text { purchase } \\
\text { intention } \\
\text { towards fast } \\
\text { fashion } \\
\text { products }\end{array}$ & $\begin{array}{l}\text { Empirica } \\
\text { l: } \\
\text { Quantitat } \\
\text { ive }\end{array}$ & $\begin{array}{l}\text { Textile and } \\
\text { apparel }\end{array}$ \\
\hline $\begin{array}{l}\text { Olya and } \\
\text { Akhshik [55] }\end{array}$ & $\begin{array}{l}\text { Demographic, } \\
\text { value, belief, } \\
\text { and norm, } \\
\text { attitude, pro- } \\
\text { environmental } \\
\text { intention }\end{array}$ & $\begin{array}{l}\text { Empirica } \\
\text { l: } \\
\text { Quantitat } \\
\text { ive }\end{array}$ & Travel \\
\hline
\end{tabular}

As a conclusion, in terms of academic discussion, with respect to the best knowledge, the current research which focusing on the scope of intention to practise solid waste segregation-at-source is very limited. Taken together with the information portrayed in Table 1 , this research can be seen as a major contribution whereby this research discovers the necessary to enrich the scarce literature on the relationship between attitude and intention to practise solid waste segregation-at-source; descriptive norm and intention to practise solid waste segregation-at-source; injunctive norm and intention to practise solid waste segregation-atsource; as well as the extent of environmental concern and environmental knowledge act as a mediator and moderator on these relationships respectively.

\section{METHODOLOGY}

In this research, the measurement of a dependent variable, i.e. intention to practise solid waste segregation-at-source is completed by using eight closed-end questions which intended to picture the tendency to carry out the repeated action of segregating unwanted materials based on their recycling potential in respondents' daily routine. The measuring items for the dependent variable is adapted from Ayob, Sheau-Ting, Abdul Jalil, and Chin [56], Fornara et al. [28], Ghani, Rusli, Biak, and Idris [57], Ioannou et al. [40] as well as Tonglet, Phillips, and Bates [58]. Consequently, a five-point Likert scale which ranging from (1) strongly disagree to (5) strongly agree is employed to measure this current dependent variable in research. Table 2 displays the items to measure the intention to practise solid waste segregation-at-source.
Table 2: Measurement Item of Intention to Practise Solid Waste Segregation-at-Source

\begin{tabular}{|c|c|c|}
\hline No. & Item & Source \\
\hline 1. & $\begin{array}{l}\text { I truly intend to separatemy } \\
\text { household solid waste at homeas } \\
\text { much as possible in the next three } \\
\text { months. }\end{array}$ & $\begin{array}{l}\text { Ioannouet al. } \\
{[40]}\end{array}$ \\
\hline 2. & $\begin{array}{l}\text { I am willing to segregate piles of } \\
\text { household solid waste into } \\
\text { different categories if proper wast } \\
\text { segregation facilities are provided. }\end{array}$ & \\
\hline 3. & $\begin{array}{l}\text { I will try my best to separate most } \\
\text { of my hou sehold solid waste at } \\
\text { home if I am convinced with the } \\
\text { benefits of solid waste }\end{array}$ & \\
\hline 4. & $\begin{array}{l}\text { segregation-at-source. } \\
\text { I will make an effort to segregate } \\
\text { my hou sehold solid waste at home } \\
\text { if the local authority enforces } \\
\text { public participation in solid waste } \\
\text { serregation-at-source. }\end{array}$ & $\begin{array}{l}\text { Ghani et al. [57]; } \\
\text { Tonglet et al. } \\
\text { [58] }\end{array}$ \\
\hline 5. & $\begin{array}{l}\text { I plan to separate my hou sehold } \\
\text { solid waste at home if the local } \\
\text { authority provides satis factory } \\
\text { services for the separated } \\
\text { household solid waste collection. }\end{array}$ & \\
\hline 6. & $\begin{array}{l}\text { I expect that I will take part in } \\
\text { solid waste segregation-at-s ource } \\
\text { activities if I am satis fied with the } \\
\text { household garbage collection } \\
\text { measures by the local authorities. } \\
\text { I have the tendency to separate }\end{array}$ & \\
\hline & $\begin{array}{l}\text { unwanted household solid waste } \\
\text { according to their recycling } \\
\text { potential systematically. }\end{array}$ & $\begin{array}{l}\text { Ayob et al. [56]; } \\
\text { Fornara et al. } \\
\text { [28] }\end{array}$ \\
\hline 8. & $\begin{array}{l}\text { I will be willing to support the } \\
\text { mandatory solid waste } \\
\text { segregation-at-source policy under } \\
\text { the Solid Waste and Public } \\
\text { Cleansing Management Act } 2007 \\
\text { (Act 672). }\end{array}$ & \\
\hline
\end{tabular}

The attitude measurement of respondents in this current research is designed by adapting the scale applied in previous research [58-60]. There are fourteen statements framed to interpret the attitude of respondents on the intention to practise solid waste segregation-at-source.

Out of these fourteen items, three items are negatively stated. Thus, the negative statement items are well reverse coded before data analysis takes place. This section is measured based on a 5-point Likert scale which ranged from "option 1" for "strongly disagree" to "option 5" for "strongly agree". This is used to indicate the degree of agreement or disagreement of respondents towards each of the statement. In other words, respondents are required to rate whether they agree with the statements by providing their responses according to the five response categories in a bid to reflect their attitude on the intention to practise solid waste segregation-at-source. Table 3 displays the items to measure the attitude with the intention to practise solid waste segregation-at-source. 
Table 3: Measurement Item of Attitude with Intention to Practise Solid Waste Segregation-at-Source

\begin{tabular}{|c|c|c|}
\hline No. & lterl & Sourct \\
\hline 1. & 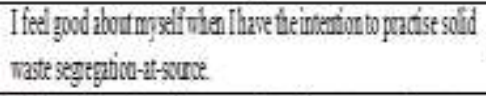 & Zhargetal. [00] \\
\hline 2 & 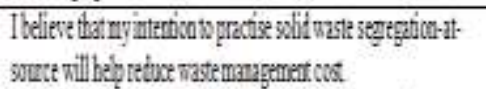 & \multirow{4}{*}{ Tongetetal [58] } \\
\hline 3. & 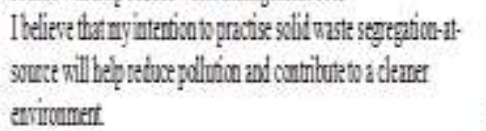 & \\
\hline 4. & 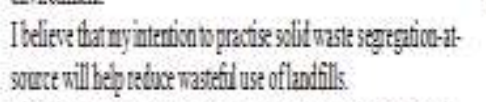 & \\
\hline 5. & 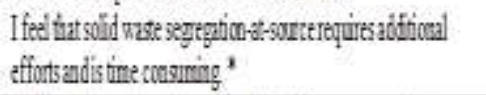 & \\
\hline 6. & 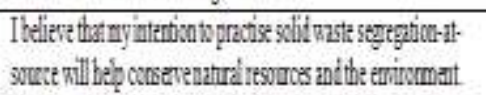 & \multirow{5}{*}{ Tongetetal $[8 \mathrm{~B}]$} \\
\hline 7. & 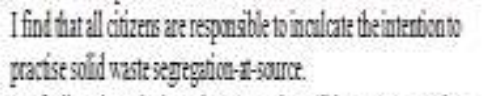 & \\
\hline 8 & 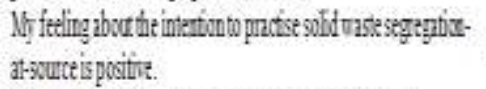 & \\
\hline 9. & 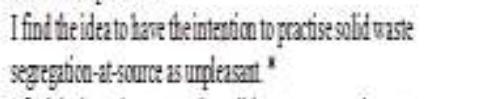 & \\
\hline 10. & 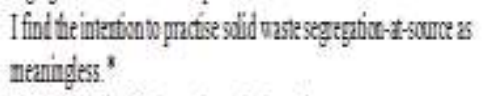 & \\
\hline 11. & 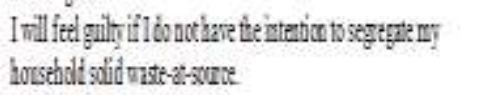 & \multirow{4}{*}{ Babue at 1. [99] } \\
\hline 12. & 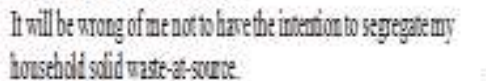 & \\
\hline 13. & 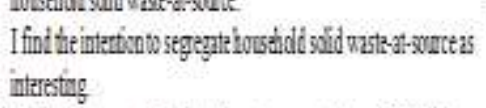 & \\
\hline 14. & 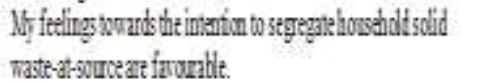 & \\
\hline
\end{tabular}

Notec $=$ neggive stiment

Next, there are twelve positive statements designed to verify the descriptive norm of respondents on the concept of intention to practise solid waste segregation-at-source. Descriptive norm was measured by using the questionnaire proposed in previous research [28,61-67].

It is noted that the respondents' rates ranged from 1 "never" to 5 "always". Respondents are requested how well each of the twelve different statements describes them by using a five-point response format. A total of the score will be computed in a bid to analyse the descriptive norm with the intention to practise solid waste segregation-at-source. Subsequently, the range of score is a minimum score of 12 and a maximum score of 60 . Hence, the higher the score corresponds to a better descriptive norm on the intention to practise solid waste segregation-at-source. Table 4 shows the items to measure the descriptive norm with the intention to practise solid waste segregation-at-source.
Table 4: Measurement Item of Descriptive Norm with Intention to Practise Solid Waste Segregation-at-Source

\begin{tabular}{|c|c|c|}
\hline $\mathrm{Ya}$ & Irem & Sourte \\
\hline 1. & 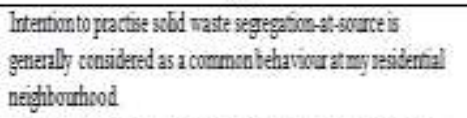 & Bitas ex: al [64] \\
\hline 2. & 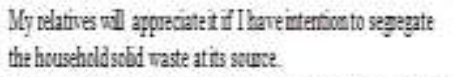 & \\
\hline 3. & 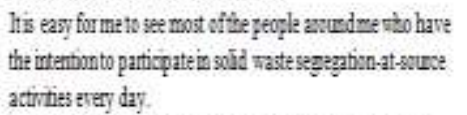 & Lapmskiet al [66] \\
\hline 4. & 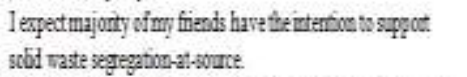 & \\
\hline 5. & 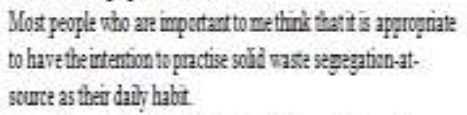 & \\
\hline 6. & 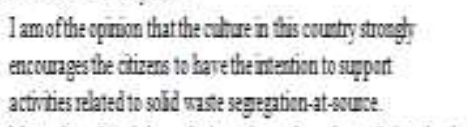 & Bonenamanet al [65]] \\
\hline 7. & 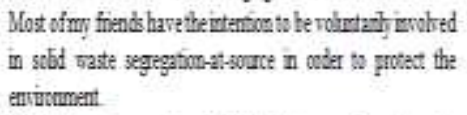 & Fumanetal [R] \\
\hline 8. & 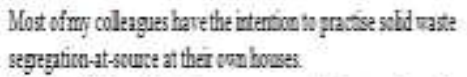 & \\
\hline 9. & 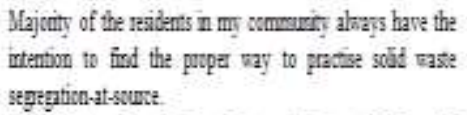 & Enksson andFernad [62] \\
\hline 10. & 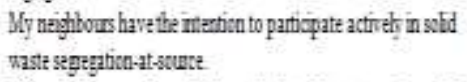 & Cotherg at al [61] \\
\hline 11. & 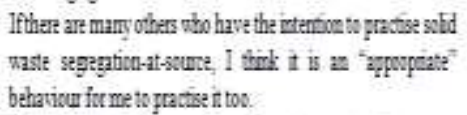 & Pathet al [6] \\
\hline 12. & 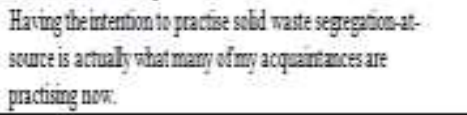 & Jacobsenetal [6]] \\
\hline
\end{tabular}

Besides that, there are twelve positive statements which measure the injunctive norm with the intention to practise solid waste segregation-at-source as shown in Table 5. It is further noted that these questions are adapted from Fornara et al. [28], Park et al. [67], Leavens, Brett, Morgan, Lopez, Shaikh, Leffingwell, and Wagener [68], and Minton and Rose [69]. This section measures how does injunctive norm can influence the intention to practise solid waste segregation-at-source. The five-point Likert-type scale which ranged from 1 "strongly disapprove" to 5 "strongly approve" is used in order to rate the respond of respondents towards the statements in this section. The total score of this construct is then computed in order to interpret the raw scores in a more manageable way. Subsequently, the summated scores are further segregated into three categories, namely Low (12-27), Moderate (28-44), and High (45-60). To conclude, the higher the score, the higher the injunctive norm towards intention to practise solid waste segregation-at-source. 
International Conference on Recents Advancements in Engineering and Technology (ICRAET-18) |15th and 16th March 2019|Siddhartha Institute of Technology \& Sciences, Telangana, India.

Table 5: Measurement Item of Injunctive Norm with Intention to Practise Solid Waste Segregation-at-Source

\begin{tabular}{|c|c|c|}
\hline S. & IfruI & Sourt \\
\hline 1 & 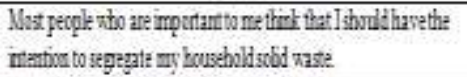 & Fomarast al[2] \\
\hline 2 & 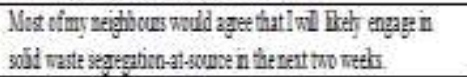 & \multirow{7}{*}{ Mrrm and Rose $[69$} \\
\hline 3. & 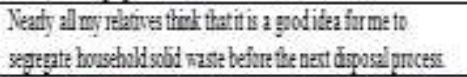 & \\
\hline 1 & 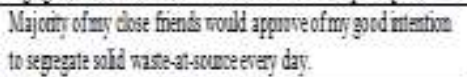 & \\
\hline 5 & 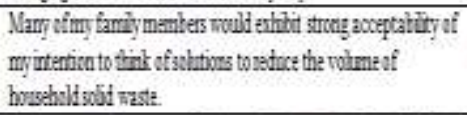 & \\
\hline 6 & 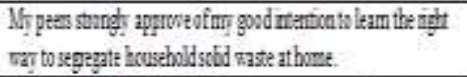 & \\
\hline 7. & 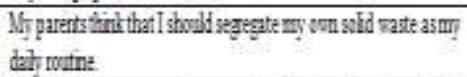 & \\
\hline 8 & 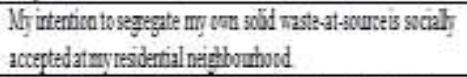 & \\
\hline 9 & 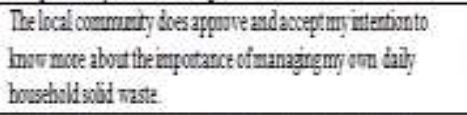 & Mrrinand Rose 169 \\
\hline 10. & 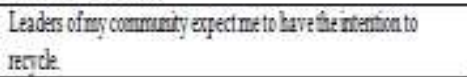 & \\
\hline II. & 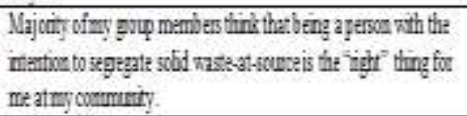 & Patk tal $[6]$ \\
\hline 12. & 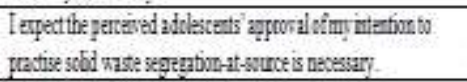 & Lavanstal[68] \\
\hline
\end{tabular}

Next, environmental concern encompassing three dimensions of environmental concern, namely egoistic concern, altruistic concern and biospheric concern. A total of twelve positive closed-end questions are designed to observe the three dimensions of environmental concern towards the intention to practise solid waste segregation-atsource. This section is adapted from the previous research of Stern and Dietz [70]. Respondents were asked to choose the most appropriate response to measure the intensity of respondents' view with respect to the statements constructed in this section in order to test the mediating variable of environmental concern in this research. Consequently, the five-point Likert scale ranges from (1) strongly disagree to (5) strongly agree [71] is used to measure in this section. Respondents need to think about to what extent they agree with the set of statements as shown in Table 6.
Table 6: Measurement Item of Environmental Concern with Intention to Practise Solid Waste Segregation-at-Source

\begin{tabular}{|c|c|c|}
\hline $\mathrm{Na}$ & Iteat & Sourse \\
\hline \multicolumn{3}{|c|}{ Egointic coscen: } \\
\hline 1 & 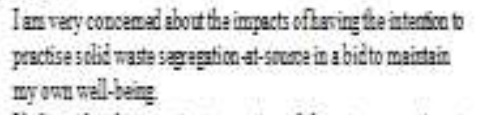 & \\
\hline \multirow[t]{2}{*}{2} & 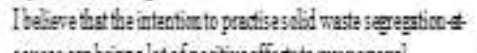 & \\
\hline & $\begin{array}{l}\text { souece car bring a lot of postivadfats to ny perval } \\
\text { lifestyla. }\end{array}$ & Sem andDistr [0] \\
\hline 3. & 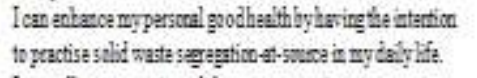 & \\
\hline 4. & 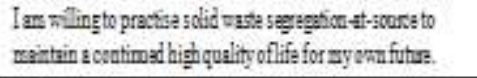 & \\
\hline \multicolumn{3}{|c|}{ Altruirtic coscers: } \\
\hline 5. & 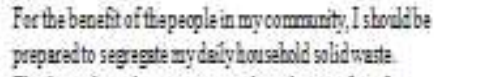 & \\
\hline 6. & 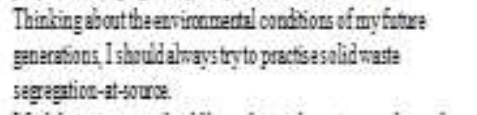 & \\
\hline 7. & 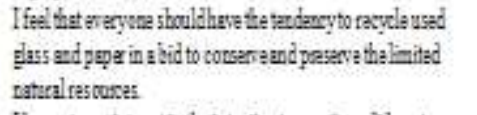 & \\
\hline \multirow[t]{2}{*}{8.} & 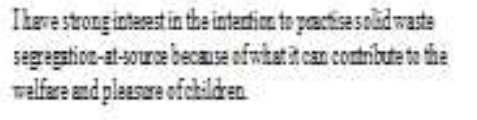 & \\
\hline & Biogpheric coacen: & Sten andDiatr [70] \\
\hline 9. & 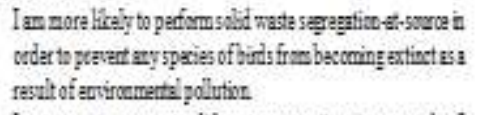 & \\
\hline 10. & 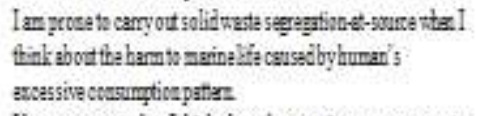 & \\
\hline 11. & 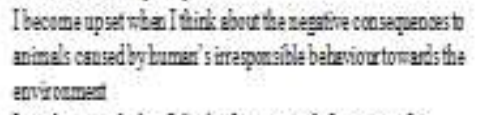 & \\
\hline 12. & 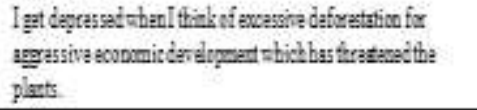 & \\
\hline
\end{tabular}

Lastly, this research measures the moderating effect of environmental knowledge by adapting the instruments developed by Bang, Ellinger, Hadjimarcou, and Traichal [72], Braun and Dierkes [73], Gambro and Switzky [74], Paço and Lavrador [75], Ramayah, Lee, and Lim [76], and Safari, Salehzadeh, Panahi, and Abolghasemian [77], based on the Malaysian context. The instrument in the present research consists of 25 statements. The negative statements in this section are well reverse coded before data analysis takes place. The rating consists of a five-point Likert-type scale and range from 1 "never true" to 5 "always true". The synthesis of scale can be obtained by aggregating the value and divide the value accordingly. Table 7 displays the items to measure environmental knowledge with the intention to practise solid waste segregation-at-source. 
Table 7: Measurement Item of Environmental Knowledge with Intention to Practise Solid Waste Segregation-at-Source

\begin{tabular}{|c|c|c|}
\hline$Y_{0}$ & Iften & Saurce \\
\hline 1. & 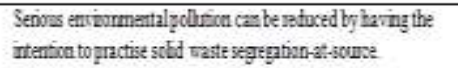 & \\
\hline 2. & 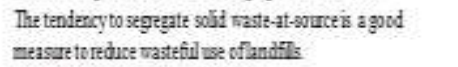 & 7amathet al[ [6] \\
\hline 3. & 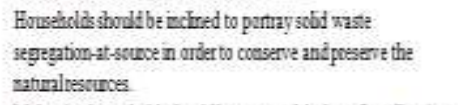 & \\
\hline 4. & 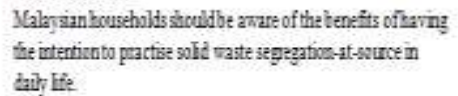 & \\
\hline 5. & 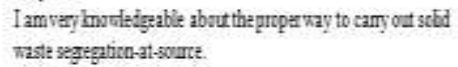 & Banget al [72] \\
\hline 6. & 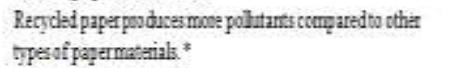 & \\
\hline 2. & 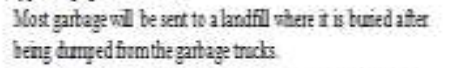 & \\
\hline 8. & 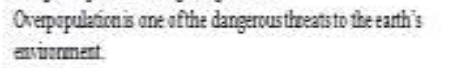 & \\
\hline 9. & $\begin{array}{l}\text { Recycing means that hrusebold baysthing that canbe ased } \\
\text { agin }\end{array}$ & \\
\hline 10 & $\begin{array}{l}\text { Arimals alne today aremost itely to beccome esint if their } \\
\text { habiatis destroyed }\end{array}$ & \\
\hline 11 & 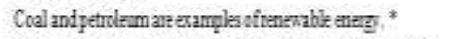 & \\
\hline 12 & $\begin{array}{l}\text { Eninumertal problems are a theatorly to husseboldin the } \\
\text { atis: }\end{array}$ & Gamben andSritzy $[4]$ \\
\hline 13. & $\begin{array}{l}\text { The manproblem vith lanifils is that they takeup too muth } \\
\text { space. }\end{array}$ & \\
\hline 14 & $\begin{array}{l}\text { Builfng a damos a rive car be hamifil becusait makes the } \\
\text { iver modby. }\end{array}$ & \\
\hline 15. & An example of nouserevable enagy is idal vare energy. " & \\
\hline 16. & $\begin{array}{l}\text { Ahmrium can is an example of tems vtich camntberecydad } \\
\text { anivessed. }\end{array}$ & \\
\hline 17. & Species that na longer erists should be protectad. * & \\
\hline 18. & Defurestation causes a dry an andhutter fimate. & \\
\hline 19. & 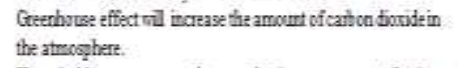 & \\
\hline 20 & 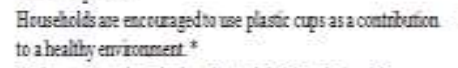 & Branandiekas [3] \\
\hline 21 & 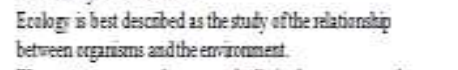 & \\
\hline 22 & 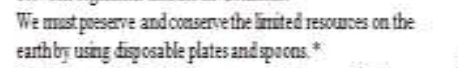 & \\
\hline 23. & $\begin{array}{l}\text { Raticaly, al the lead n wr atmosphereis consedty theurage } \\
\text { of cars. }\end{array}$ & Safane al [7]] \\
\hline 24 & 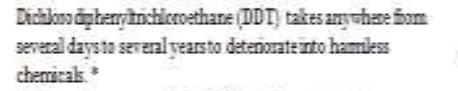 & Paģo andLavrader [5] \\
\hline 25. & Ecelogy tiexs man asbang dfferent fom nanue. ${ }^{*}$ & \\
\hline
\end{tabular}

\section{RESULTS AND FINDINGS}

A good measurement must meet the tests of validity and reliability. This research has attempted to assess validity in many ways. The four basic approaches to establishing validity are face validity, content validity, criterion validity, and construct validity.

Face validity refers to a scale's content logically appears to reflect what was intended to be measured. It evaluates the feasibility, readability, consistency of style and formatting with the appropriateness of language and term usage in the questionnaire [78]. Face validity is also a subjective judgement on the operationalisation of construct and judgement which can be made by non-experts such as the respondents of the pilot test [79]. Thus, the feedbacks from pre-test by participants will be also used to validate the instrument [80]. Meanwhile. in order to ensure the high appropriateness of this current research, a panel of experts from the field of consumer sciences will be gathered to evaluate the instruments prior to the pre-test. Changes will be made according to the suggestion from the experts. Consequently, the pre-test of this research was conducted from 1st January 2019 to 15 th January 2019. In the pre-test section, a total of thirty Malaysian households regardless of races, religions, and ages were chosen randomly to complete the bilingual self-administrated instrument. There is a 100.0 per cent response rate in which the researcher received good feedback from the surveyed respondents.

Content validity refers to the degree that a measure covers the breadth of the domain of interest. It also addresses the match between test questions and variables that intended to be assessed [81]. This concept of the match is sometimes interpreted as alignment while the variable of the test may be referred [82]. As a result, the content validity in this research is enhanced by using the established dimensions and instruments from previous research.

Criterion validity is the ability of a measure to be correlated with other standard measures of similar constructs or established criteria. A researcher must make sure whether the measure that he used is practical throughout the research. Therefore, criterion validity can be applied by using a correlation coefficient in this research. The higher the correlation, the higher the validity of the instrument [83].

Construct validity exists when a measure reliably measures and truthfully represents a unique concept. Construct validity consists of several components, including face validity, content validity, criterion validity, convergent validity, and discriminant validity. Before a researcher moves further, he must be sure his measures look like they are measuring what they are intended to measure (face validity) and adequately cover the domain of interest (content validity). If so, a researcher can assess convergent validity and discriminant validity.

Convergent validity refers to the concepts that should be related to one another and in fact related. In this research, convergent validity is examined by using average variance extracted (AVE) in order to determine whether each construct have a wide range, or they are more or less similar [84]. Bagozzi and Yi [85] also explained that convergent validity for a model can be confirmed if all the AVE values are ideally greater than the acceptable threshold value of 0.50 , meaning that 50 per cent or more variance of the indicators should be accounted for measured constructs.

Lastly, discriminant validity represents how unique or district is a measure. Fornell-Larcker criterion and crossloadings are two sets of information which can be used to test the discriminant validity in a model. However, a specific construct should not correlate too highly with a measure of a different construct. This is because the specific construct should not have a stronger connection with another construct that it attempts to reflect. Chin [86] mentioned that a researcher should expect to see the item loadings to be higher than the cross-loadings while going down a particular column of the construct. If this is found to be the case, therefore, the discriminant validity can be proved in the research. 
On the other hand, reliability can be tested by using composite reliability. Composite reliability is a measure of internal consistency [87]. More specifically, it can assess the inter-item reliability for each of the multi-item variables [88]. This concept will enable researchers to obtain some assessment of the item's validity and the likely reliability of the data to be collected.

A questionnaire with high accuracy means that the information gathered is reliable and valid. The accepted value for composite reliability should be 0.700 or higher [89-90]. However, Bagozzi and Yi [85] argued that the value of 0.600 or higher is still acceptable if it is exploratory research. As a result, Table 8 reports the assessment of composite reliability for each variable measured during the pre-test of this research.

Table 8: Summary of Composite Reliability for the Pre-Test of Research

\begin{tabular}{|c|c|c|c|}
\hline Section & Variable & $\begin{array}{l}\text { Number } \\
\text { of items }\end{array}$ & $\begin{array}{c}\text { Composite } \\
\text { reliability } \\
(\mathbf{N}=\mathbf{3 0})\end{array}$ \\
\hline $\mathrm{A}(\mathrm{I})$ & $\begin{array}{l}\text { Respondent's } \\
\text { particulars }\end{array}$ & 11 & $\begin{array}{c}\text { Not } \\
\text { applicable }\end{array}$ \\
\hline $\mathrm{A}(\mathrm{II})$ & $\begin{array}{l}\text { General questions on } \\
\text { solid waste } \\
\text { segregation-at-source }\end{array}$ & 7 & $\begin{array}{c}\text { Not } \\
\text { applicable }\end{array}$ \\
\hline B & Attitude & 14 & 0.779 \\
\hline $\mathrm{C}$ & Descriptive norm & 12 & 0.919 \\
\hline $\mathrm{D}$ & Injunctive norm & 12 & 0.940 \\
\hline $\mathrm{E}$ & Environmental concern & 12 & 0.881 \\
\hline $\mathrm{F}$ & $\begin{array}{l}\text { Environmental } \\
\text { knowledge }\end{array}$ & 25 & 0.810 \\
\hline G & $\begin{array}{l}\text { Intention to practise } \\
\text { solid waste } \\
\text { segregation-at-source }\end{array}$ & 8 & 0.919 \\
\hline
\end{tabular}

Based on Table 8, all the composite reliability is beyond the suggested threshold of 0.700 . The highest value of composite reliability comes from the injunctive norm (Section D), which is 0.940 . However, the lowest value of which comes from attitude (Section B), which is 0.779 , and it is still above 0.700 , a recommended threshold of reliability. As a conclusion, the internal consistencies of all variables are acceptable for further data analyses since each reliability testing exceeds the suggested threshold of 0.700 . Hence, the measurement instrument for this present research is accepted and reliable.

\section{CONCLUSION}

The final version of the instrument is set in both closed and open format which consists of eight sections: respondent's particulars (11 items), general questions on solid waste segregation-at-source (7 items), attitude (14 items), descriptive norm (12 items), injunctive norm (12 items), environmental concern (three sub-parts and 12 items), environmental knowledge ( 25 items), and intention to practise solid waste segregation-at-source ( 8 items). The instrument can further be used to examine other similar research areas such as sustainable consumption, recycling as well as solid waste management.

\section{ACKNOWLEDGMENT}

The authors would like to thank all the residents, enumerators, and any other parties who are involved directly or indirectly in the pilot test for this research.

\section{REFERENCES}

1. Begum RA, Siwar C, Pereira JJ, Jaafar AH. Factors and values of willingness to pay for improved construction waste management-A perspective of Malaysian contractors. Waste management. 2007 Jan 1;27(12):1902-9.

2. Bong CP, Ho WS, Hashim H, Lim JS, Ho CS, Tan WS, Lee CT. Review on the renewable energy and solid waste management policies towards biogas development in Malaysia. Renewable and Sustainable Energy Reviews. 2017 Apr 1;70:988-98.

3. Sakawi Z. Municipal solid waste management in Malaysia: Solution for sustainable waste management. Journal of Applied Sciences in Environmental Sanitation. 2011 Mar 1;6(1):29-38.

4. Manaf LA, Samah MA, Zukki NI. Municipal solid waste management in Malaysia: Practices and challenges. Waste management. 2009 Nov 1;29(11):2902-6.

5. Budhiarta I, Siwar C, Basri H. Current status of municipal solid waste generation in Malaysia. International Journal on Advanced Science, Engineering and Information Technology. 2012;2(2):129-34.

6. Abas MA, Wee ST. The issues of policy implementation on solid waste management in Malaysia. International Journal of Conception on Management and Social Sciences. 2014;2(3):12-7.

7. Jeong E, Jang SS, Day J, Ha S. The impact of ecofriendly practices on green image and customer attitudes: An investigation in a café setting. International Journal of Hospitality Management. 2014 Aug 1;41:10-20.

8. Murad W, Siwar C. Waste management and recycling practices of the urban poor: a case study in Kuala Lumpur city, Malaysia. Waste management \& research. $2007 \mathrm{Feb} ; 25(1): 3-13$.

9. Knussen C, Yule F, MacKenzie J, Wells M. An analysis of intentions to recycle household waste: The roles of past behaviour, perceived habit, and perceived lack of facilities. Journal of environmental psychology. 2004 Jun 1;24(2):237-46.

10. Boyle J. Cultural influences on implementing environmental impact assessment: insights from Thailand, Indonesia, and Malaysia. Environmental Impact Assessment Review. 1998 Mar 1;18(2):95-116.

11. Beavan C. How to be alive: A guide to the kind of happiness that helps the world. New York, NY: HarperCollins; 2016.

12. Ifegbesan A. Exploring Secondary School Students' Understanding and Practices of Waste Management in Ogun State, Nigeria. International Journal of Environmental and Science Education. 2010 Apr;5(2):201-15.

13. Bacinschi Z, Rizescu CZ, Stoian EV, Necula C. Waste management practices used in the attempt to protect the environment. InProceedings of the 3rd WSEAS international conference on Engineering mechanics, structures, engineering geology 2010 Jul 22 (pp. 378382). World Scientific and Engineering Academy and Society (WSEAS)

14. Pappu A, Saxena M, Asolekar SR. Solid wastes generation in India and their recycling potential in 
building materials. Building and environment. 2007 Jun 1;42(6):2311-20.

15. Masud MM, Al-Amin AQ, Junsheng $\mathrm{H}$, Ahmed $\mathrm{F}$, Yahaya SR, Akhtar R, Banna H. Climate change issue and theory of planned behaviour: relationship by empirical evidence. Journal of Cleaner Production. 2016 Feb 1;113:613-23.

16. Stapp WB. Development, Implementation, and Evaluation of Environmental Education Programs (K12). 1973 Jan 1.

17. Lucko BJ, Disinger JF, Roth RE. Evaluation of environmental education programs at the elementary and secondary school levels. The Journal of Environmental Education. 1982 Jun 1;13(4):7-12.

18. McKeown R, Hopkins C. EE p ESD: Defusing the worry. Environmental education research. $2003 \mathrm{Feb}$ 1;9(1):117-28.

19. Fasolya O. The System of Environmental Education in the USA. Comparative Professional Pedagogy. 2016 Sep $1 ; 6(3): 85-90$.

20. Shamuganathan S, Karpudewan M. Modeling Environmental Literacy of Malaysian Pre-University Students. International Journal of Environmental and Science Education. 2015;10(5):757-71.

21. Saeed MO, Hassan MN, Mujeebu MA. Assessment of municipal solid waste generation and recyclable materials potential in Kuala Lumpur, Malaysia. Waste management. 2009 Jul 1;29(7):2209-13.

22. The Star Online. (2019, January 26). 60\% of Malaysians do not dispose of garbage properly - Nation. Retrieved from

https://www.thestar.com.my/news/nation/2019/01/26/60of-malaysians-do-not-dispose-of-garbage-properly/

23. Eusuf MA, Ibrahim M, Din SA, Islam R. Solid waste generation characteristics: The Malaysian local authorities' outlook. Planning Malaysia Journal. 2011

24. Nolan JM, Schultz PW, Cialdini RB, Goldstein NJ, Griskevicius V. Normative social influence is underdetected. Personality and social psychology bulletin. $2008 \mathrm{Jul}$;4(7):913-23. McKimmie BM. Social influence in the theory of planned behaviour: The role of descriptive, injunctive, and in?group norms. British Journal of Social Psychology. 2009 Mar;48(1):135-58.

26. Ohtomo S, Hirose Y. The dual-process of reactive and intentional decision-making involved in eco-friendly behavior. Journal of environmental psychology. 2007 Jun $1 ; 27(2): 117-25$

27. Smith JR, Louis WR, Terry DJ, Greenaway KH, Clarke MR, Cheng X. Congruent or conflicted? The impact of injunctive and descriptive norms on environmental intentions. Journal of Environmental Psychology. 2012 Dec 1;32(4):353-61.

28. Fornara F, Carrus G, Passafaro P, Bonnes M. Distinguishing the sources of normative influence on proenvironmental behaviors: The role of local norms in household waste recycling. Group Processes \& Intergroup Relations. 2011 Sep;14(5):623-35.

29. Kim H, Lee EJ, Hur WM. The mediating role of norms in the relationship between green identity and purchase Review. 2012 Dec 1:125-35.

30. Lapinski MK, Rimal RN, DeVries R, Lee EL. The role of group orientation and descriptive norms on water conservation attitudes and behaviors. Health communication. 2007 Aug 8;22(2):133-42.

31. Staats H, Jansen L, Thøgersen J. Greening the greenhouse grower. A behavioral analysis of a sectorinitiated system to reduce the environmental load of Nov 30;9(2).

25. White KM, Smith JR, Terry DJ, Greenslade JH, intention of eco-friendly products. Human Ecology

greenhouses. Journal of environmental management. 2011 Oct 1;92(10):2461-9.

32. Kok G, Siero S. Tin recycling: Awareness, comprehension, attitude, intention and behavior. Journal of economic psychology. 1985 Jun 1;6(2):157-73.

33. Davies J, Foxall GR, Pallister J. Beyond the intentionbehaviour mythology: an integrated model of recycling. Marketing theory. 2002 Mar;2(1):29-113.

34. Chen MF, Tung PJ. The moderating effect of perceived lack of facilities on consumers' recycling intentions. Environment and Behavior. 2010 Nov;42(6):824-44.

35. Mahmud SN, Osman K. The determinants of recycling intention behavior among the Malaysian school students: an application of theory of planned behaviour. ProcediaSocial and Behavioral Sciences. 2010 Jan 1;9:119-24.

36. Ramayah T, Lee JW, Mohamad O. Green product purchase intention: Some insights from a developing country. Resources, conservation and recycling. 2010 Oct 1;54(12):1419-27.

37. Ittiravivongs A. Household waste recycling behavior in Thailand: the role of responsibility. In2012 International Conference on Future Environment and Energy. International Proceedings of Chemical, Biological and Environmental Engineering 2012 Feb (Vol. 28, No. 2, pp. 21-26).

38. Fröhlich G, Sellmann D, Bogner FX. The influence of situational emotions on the intention for sustainable consumer behaviour in a student-centred intervention. Environmental Education Research. 2013 Dec 1;19(6):747-64

39. Ho ST, Tong DY, Ahmed EM, Lee CT. Factors influencing household electronic waste recycling intention. InAdvanced Materials Research 2013 (Vol. 622, pp. 1686-1690). Trans Tech Publications.

40. Ioannou T, Zampetakis LA, Lasaridi K. Psychological determinants of household recycling intention in the context of the theory of planned behaviour. Fresenius Environmental Bulletin. 2013 Jan 1;22(1):2035-41.

41. Lee SY, Kang M. Innovation characteristics and intention to adopt sustainable facilities management practices. Ergonomics. 2013 Mar 1;56(3):480-91.

42. Kil N, Holland SM, Stein TV. Place meanings and participatory planning intentions. Society \& Natural Resources. 2014 May 1;27(5):475-91.

43. Wan $\mathrm{C}$, Shen GQ, Yu A. The moderating effect of perceived policy effectiveness on recycling intention. Journal of Environmental Psychology. 2014 Mar $1 ; 37: 55-60$

44. Nguyen TT, Zhu D, Le NP. Factors influencing waste separation intention of residential households in a developing country: Evidence from Hanoi, Vietnam. Habitat International. 2015 Aug 1;48:169-76.

45. Tonge J, Ryan MM, Moore SA, Beckley LE. The effect of place attachment on pro-environment behavioral intentions of visitors to coastal natural area tourist destinations. Journal of Travel Research. 2015 Nov;54(6):730-43.

46. Periyayya T, Nair GV, Shariff R, Roland Z, Thanaseelan D. Young adult Malaysian consumers' attitude and purchase intentions of CSR supported grocery brands. Journal of the Southeast Asia Research Centre for Communications and Humanities. 2016 Mar 1;8(1):5677.

47. Echegaray F, Hansstein FV. Assessing the intentionbehavior gap in electronic waste recycling: the case of Brazil. Journal of Cleaner Production. 2017 Jan 20;142:180-90. 
48. Khor KS, Hazen BT. Remanufactured products purchase intentions and behaviour: Evidence from Malaysia. International Journal of Production Research. 2017 Apr 18;55(8):2149-62.

49. Kiatkawsin K, Han H. Young travelers' intention to behave pro-environmentally: Merging the value-beliefnorm theory and the expectancy theory. Tourism Management. 2017 Apr 1;59:76-88.

50. Wan C, Shen GQ, Choi S. Experiential and instrumental attitudes: Interaction effect of attitude and subjective norm on recycling intention. Journal of Environmental Psychology. 2017 Jun 1;50:69-79.

51. Pan SL, Chou J, Morrison A, Huang WS, Lin MC. Will the Future Be Greener? The Environmental Behavioral Intentions of University Tourism Students. Sustainability. 2018 Mar;10(3):634.

52. Vassanadumrongdee S, Kittipongvises S. Factors influencing source separation intention and willingness to pay for improving waste management in Bangkok, Thailand. Sustainable Environment Research. 2018 Mar 1;28(2):90-9.

53. Verma VK, Chandra B. An application of theory of planned behavior to predict young Indian consumers' green hotel visit intention. Journal of cleaner production. 2018 Jan 20;172:1152-62.

54. Vuong HG, Nguyen MT. Factors Influencing Millennials' Purchase Intention towards Fast Fashion Products: A Case Study in Vietnam. International Journal of Social Science and Humanity. 2018 Aug;8(8).

55. Olya HG, Akhshik A. Tackling the complexity of the pro-environmental behavior intentions of visitors to turtle sites. Journal of Travel Research. 2019 Feb;58(2):313 32.

56. Ayob SF, Sheau-Ting L, Abdul Jalil R, Chin HC. Key determinants of waste separation intention: empirical application of TPB. Facilities. 2017 Aug 8;35(11/12):696-708.

57. Ghani WA, Rusli IF, Biak DR, Idris A. An application of the theory of planned behaviour to study the influencing factors of participation in source separation of food waste. Waste Management. 2013 May 1;33(5):1276-81.

58. Tonglet M, Phillips PS, Bates MP. Determining the drivers for householder pro-environmental behaviour: waste minimisation compared to recycling. Resources, conservation and recycling. 2004 Aug 1;42(1):27-48.

59. Babaei AA, Alavi N, Goudarzi G, Teymouri P, Ahmadi K, Rafiee M. Household recycling knowledge, attitudes and practices towards solid waste management. Resources, Conservation and Recycling. 2015 Sep 1;102:94-100.

60. Zhang D, Huang G, Yin X, Gong Q. Residents' waste separation behaviors at the source: Using SEM with the theory of planned behavior in Guangzhou, China. International journal of environmental research and public health. 2015 Aug;12(8):9475-91.

61. Culiberg B, Elgaaied?Gambier L. Going green to fit inunderstanding the impact of social norms on pro?environmental behaviour, a cross?cultural approach. International journal of consumer studies. 2016 Mar;40(2):179-85.

62. Eriksson L, Forward SE. Is the intention to travel in a pro-environmental manner and the intention to use the car determined by different factors? Transportation research part D: transport and environment. $2011 \mathrm{Jul}$ 1;16(5):372-6.

63. Jacobson RP, Jacobson KJ, Hood JN. Social norm perceptions predict citizenship behaviors. Journal of Managerial Psychology. 2015 Nov 9;30(8):894-908.

64. Köbis NC, van Prooijen JW, Righetti F, Van Lange PA. Prospection in individual and interpersonal corruption dilemmas. Review of General Psychology. 2016 Mar;20(1):71-85.

65. Koeneman MA, Chorus A, Hopman-Rock M, Chinapaw MJ. A novel method to promote physical activity among older adults in residential care: an exploratory field study on implicit social norms. BMC geriatrics. 2017 Dec;17(1):8.

66. Lapinski MK, Zhuang J, Koh H, Shi J. Descriptive norms and involvement in health and environmental behaviors. Communication Research. 2017 Apr;44(3):367-87.

67. Park HS, Klein KA, Smith S, Martell D. Separating subjective norms, university descriptive and injunctive norms, and US descriptive and injunctive norms for drinking behavior intentions. Health communication. 2009 Nov 30;24(8):746-51.

68. Leavens EL, Brett EI, Morgan TL, Lopez SV, Shaikh RA, Leffingwell TR, Wagener TL. Descriptive and injunctive norms of waterpipe smoking among college students. Addictive behaviors. 2018 Feb 1;77:59-62.

69. Minton AP, Rose RL. The effects of environmental concern on environmentally friendly consumer behavior: An exploratory study. Journal of Business research. 1997 Sep 1;40(1):37-48.

70. Stern PC, Dietz T. The value basis of environmental concern. Journal of social issues. 1994 Oct 1;50(3):6584.

71. De Groot JI, Steg L. Value orientations to explain beliefs related to environmental significant behavior: How to measure egoistic, altruistic, and biospheric value orientations. Environment and Behavior. 2008 May;40(3):330-54.

72. Bang HK, Ellinger AE, Hadjimarcou J, Traichal PA Consumer concern, knowledge, belief, and attitude toward renewable energy: An application of the reasoned action theory. Psychology \& Marketing. 2000 Jun;17(6):449-68.

73. Braun T, Dierkes P. Evaluating Three Dimensions of Environmental Knowledge and Their Impact on Behaviour. Research in Science Education. 2017 Sep:19.

74. Gambro JS, Switzky HN. Variables associated with American high school students' knowledge of environmental issues related to energy and pollution. The Journal of Environmental Education. 1999 Jan 1;30(2):15-22.

75. Paço A, Lavrador T. Environmental knowledge and attitudes and behaviours towards energy consumption. Journal of environmental management. $2017 \mathrm{Jul}$ 15;197:384-92.

76. Ramayah T, Lee JW, Lim S. Sustaining the environment through recycling: An empirical study. Journal of environmental management. 2012 Jul 15;102:141-7.

77. Safari A, Salehzadeh R, Panahi R, Abolghasemian S. Multiple pathways linking environmental knowledge and awareness to employees' green behavior. Corporate Governance: The international journal of business in society. 2018 Feb 5;18(1):81-103.

78. Oluwatayo JA. Validity and reliability issues in educational research. Journal of Educational and Social Research. 2012 May;2(2):391-400.

79. Hardesty DM, Bearden WO. The use of expert judges in scale development: Implications for improving face validity of measures of unobservable constructs. Journal of Business Research. 2004 Feb 1;57(2):98-107.

80. Quinlan C, Babin B, Carr J, Griffin M. Business research methods. South Western Cengage; 2019. 
81. Kimberlin CL, Winterstein AG. Validity and reliability of measurement instruments used in research. American journal of health-system pharmacy. 2008 Dec 1;65(23):2276-84.

82. Hammond JW, Moss PA. Validity Theory in Measurement. Encyclopedia of Educational Philosophy and Theory. 2016:1-5.

83. Twycross A, Shields L. Validity and reliability--what's it all about? Part 2 reliability in quantitative studies: this is one of a series of short papers on aspects of research by Alison Twycross and Linda Shields. Paediatric Nursing. 2004 Dec 1;16(10):36-7.

84. Fornell C, Larcker DF. Evaluating structural equation models with unobservable variables and measurement error. Journal of marketing research. $1981 \mathrm{Feb} ; 18(1)$ :3950 .

85. Bagozzi RP, Yi Y. On the evaluation of structural equation models. Journal of the academy of marketing science. 1988 Mar 1;16(1):74-94.

86. Chin WW. The partial least squares approach to structural equation modeling. Modern methods for business research. 1998 Jan;295(2):295-336.

87. Thurber S, Bonynge M. SEM-based composite reliability estimates of the Crisis Acuity Rating Scale with children and adolescents. Archives of Assessment Psychology. 2011 Jul 11;1(1).

88. Vellido A, Lisboa PJ, Meehan K. Quantitative characterization and prediction of on-line purchasing behavior: A latent variable approach. International journal of electronic commerce. $2000 \mathrm{Jul}$ 1;4(4):83-104.

89. Christie B, Higgins P. The impact of outdoor learning experiences on attitudes to sustainability: A brief review of literature. Field Studies Council/University of Edinburgh. Field Studies Council Report. 2012;6:2012.

90. Nunnally JC, Bernstein IH. Psychological theory. New York, NY: MacGraw-Hill. 1994:131-47. 